\title{
Unconfirmed identity as an indicator of social failure of personality in different age periods
}

\author{
Yuliya Makarevskaya ${ }^{1, *}$ and Zinaida Ryabikina $^{2}$ \\ ${ }^{1}$ Sochi State University, 94, Plastunskaya str., 354003, Sochi, Russia \\ ${ }^{2}$ Kuban State University, 149, Stavropolskaya str., 350000, Krasnodar, Russia
}

\begin{abstract}
Personal identity studies in psychology demonstrate the relevance of studying this phenomenon and the concomitant problem of selecting methods that would allow the researcher to obtain information about the underlying layers of the personality. One of the methods available for this purpose - introspection, or structured self-observation has allowed the study to obtain data on the content components, structural organization and qualitative specificity of the components of personal identity. The study shows identity factors and the intensity of identification processes in socially unsuccessful respondents. The study shows that the lack of positive reinforcement of society in the important for the individual activity is interpreted as the need to strengthen the signs of their own uniqueness. Unconfirmed identity is more intense, filled with meaningful external identification characteristics, and is a thing of the past. The analysis was carried out through the age specificity of personality identifications.
\end{abstract}

\section{Introduction}

The problem of personal identity is one of the key issues in human sciences [1,2]. This problem in philosophy, and then in psychology, historically represents a point of intersection of a number of central philosophical problems: how can the same thing be kept identical at different intervals of time; the problem of the nature and essence of the self and self-consciousness; the problem of what exactly connects an individual with the prospect of his future existence, survival or immortality.

The current state of the identity problem and its interpretation in the scientific discourse are conditioned by the general trends of the social process: the transitivity and general increase of dynamism, the informatization of society, its active political reconstruction, post-modernization of the public worldview, increasing virtualization, etc. [3-9].

The transitivity of the socio-cultural circumstances of modern existence necessitates a rethinking of the problem of personal identity and the peculiarities of its conditionality to "fluid modernity".

The identity of the individual is determined by the general trends of these changes: the informatization of society, its active political reconstruction, the postmodernization of the social worldview, the growing virtualization of being, its consumerization, etc.

\footnotetext{
*Corresponding author: yuliya-sochi@mail.ru
} 
How do these processes affect identity?

The informatization of society has expanded the variability of changing social images; the philosophy of postmodernism has legitimized the right of everyone to be different, even at the cost of violating norms. [10-12]

Virtualization of being, by protecting it from collisions with reality, has reduced the risk of disapproval used by society to maintain normality. [13, 14]

Consumerization prompts a social individual to renew himself endlessly through the acquisition of new things, distracting him from the personalization of what he has acquired.

The community of generations is violated, gaps in the age (generational) succession of the socialization of the individual are noticeable, and the personality, as you know, always belongs to a certain generation [15].

In different ethno-cultural spaces, the influence of these processes on the selfidentification of a person differs.

In the new circumstances of being, the role of the subjective (author's) position of a person in self-identification increases.

Humanistic, existential traditions in psychology, subjective-liberal approach to the analysis of personality problems create the theoretical basis for the analysis of natural links between the features of "fluid modernity" and self-identification of a person $[16,17]$.

\subsection{Project Overview}

The research is based on the thesis that personal identification is secondary to social identification.

The achievement of identity is possible only in social space. Identification initially has a certain social content; it is impossible to be alone with oneself. It can be understood as a point of intersection, an alloy of a concrete human individual (and his subjectivity) and sociality (with the whole set of objective characteristics). Interestingly, the great Other is the social order as such, the symbolic order of society.

Social reality today clearly shows the property of "mirrors": the properties of one social phenomenon (or person) are reflected in another. But it is on this very basis that the act of identification as such is kept: a person looks at the Other and finds himself at the same time. Thus, identity does not know social barriers, obstacles and differences. The concept of identity is the birth of a society dominated by social mobility, i.e., there is no rigid fixation of a person with a certain social status In a society where identity exists in the form of "given", the need for identification in the strict sense does not arise. In hierarchical sociality there is no such simple possibility to find "equations", similarities required for identification processes. In this case, it can be argued that identity and "anthropogenic", "cultural" sociality are in some ways adjusted to each other.

That is, personal identity is a product of the public, its formation (structure) and content depends on the nature of external evidence.

Undoubtedly, the identity of a person is formed and exists in social interaction, is represented in the outside world, and at the same time preserves the inner world, gives it integrity, orientation, constancy (identity).

At the current rate of social change, the risks of identity invasion are increasing, so the options of preserving the personality's inner integrity, directionality and constancy are the subject of psychologists' research. [18,19]

It is obvious that in the conditions of rapidity of transformations of social spheres today it is possible to identify socially successful and socially unsuccessful people. [20]

Success is always associated with objective characteristics (good luck, recognition of society, good results) and subjective characteristics (success, which is perceived by the individual as significant). 
In the theories of personal identity, the notions of success were associated with the understanding of the nature of man, for normal existence and mental development of which, it is necessary to simultaneously integrate with society and separate from it as an individuality, that is, the balance of social and personal identities of a person.

Integration with society, merger and unity with it are impossible without taking into account public opinion, feedback and confessions, and individualization - without striving to stand out and be recognized (not by oneself, but by society). Thus, the focus on external, socially conditioned parameters creates the main problem of dual understanding of success or failure of an individual in identity concepts.

The desire to stand out shows the need for success as one of the basic sources of personal activity. The realization of this need is presented in its various manifestations: as the basis for successful self-realization; as a tendency to self-actualization, to personal growth $[21,22]$.

That is, in the concepts of personal identity, success can be understood as awareness and maximum manifestation of one's individuality.

However, in the same concepts, the public recognition of the achievements and successes of the individual is considered to be an important factor determining the acquisition of personal integrity (as a structure generating the meaning of life and guiding personal aspirations), as well as the specifics of its content.

Society assesses the success or failure of an individual based on the presence or absence of an objective result (achievement of the goal) and the significance of the performed activity in accordance with the system of public values.

Subjective assessment of the result of the performed activity is experienced by the individual emotionally as success (pleasure, joy, etc.) or failure (disappointment, resentment, anger, etc.), as opposed to "result", which may not cause emotional experience if the activity is of little importance to the individual.

In order to realize that the subject has achieved success, it must at least carry out certain activities in a timely manner, not worse than before, and better, than others who perform the same activities.

Thus, a person's experience and conscious reflection of his or her success or failure is largely determined by reinforcements, confirmations of the social environment (or lack thereof). A person entering the society is accepted or not accepted by him, i.e. receives or does not receive positive reinforcement for his actions and deeds. Depending on the quality of society's reinforcements (positive or negative), a person understands and feels that he or she has achieved or has not achieved success, starting from each specific situation to life in general.

Objective criteria for failure can be the lack of achievement of a person in activities that are recognized by most other people around him as significant.

However, success and failure are clearly recognized and experienced not in any activity, but only in the important for the future of the individual, that is, in the sphere of activity that defines a person as a builder of their own future.

Provided that success is one of the most important values of modern society, success becomes a criterion of successful existence, this aspect of a person's life path (social success) is well studied in psychology. While social failure is not the opposite of success but a qualitatively different phenomenon, it has not been sufficiently studied. Of particular interest is the impact of social failure on personal identity.

The goals of research are to identify the specifics of self-identification characteristics of a person and the general identity index of socially unsuccessful people. 


\section{Methods}

\subsection{Participants}

The study was launched in 2006. Initially, a study was carried out to identify selfidentification characteristics of a person, in which 163 people aged 18 to 28 took part, then the sample in the study to determine the structure of identity was 100 people, the final sample of statistical comparison was 41 people.

The sample was divided into socially successful and socially unsuccessful respondents at the first stage - on the basis of the law of normal distribution (Har. $\pm \sigma$ ) by indicators of academic success of respondents, at the stage of statistical comparison - by objective indicators: permanent employment, high-status position occupied (for socially successful), long-term unemployment, alcoholization and other types of addictions, deviant/delinquent behavior (for socially unsuccessful).

In 2007, 2010, 2013, 2017, replication studies were conducted, which confirmed the set of self-identification characteristics of a person obtained in the original version. [23]

Then the factoring of the signs of personal identity was carried out, the experimental group of the study was 198 people.

Outcome Measures.

At the first stage, frequency and content analysis was used to process an array of qualitative self-identification characteristics.

It has been determined that the structure of personal identity can be divided into 5 categories, describing the self-identification characteristics of a person.

1. Character of the person. These are such self-identification characteristics as "my attitude to myself", "how I relate to other people", "my worldview", "attitude to relatives", "selfishness", "purposefulness", "attitude to the world", "beliefs", etc.

2. Individual style of activity - characteristics such as "how I usually behave", "how I do my job", "my habits", "manner of speaking", etc.

3. The focus is "what interests me," "my desires," "my interests," "sense of humor," "love of life," "my fantasy," etc.

4. Behavior. These are characteristics such "my smile", "my look", "my gait", "my mime", "my reactions", etc.

5 The temporal vector of signs includes a reference of self-identification characteristics to the past, the future, for example, "my dreams", "my plans for the future", "my knowledge of the past", etc.

Descriptive characteristics of self-identification features were included in the initial questionnaire consisting of 50 statements describing the parameters of personal identity in all 5 categories.

After processing the results of expert assessments $(N=20)$, the questionnaire contained 30 statements, which were verified on a sample of 198 people. Further, the factor analysis has identified 3 main factors of personal identity: external identification features, internal identification features, temporary orientation of identification features.

Statistical Methods

In the first stage of the study, the H-Craskala-Wallace criterion was used to determine the differences in the frequency of identification categories in the groups of subjects, the $t$ Student criterion to determine the differences in the average intensity of the features and the single-factor analysis of the ANOVA dispersion to determine the influence of the factor of social belonging to the group of socially successful/socially unsuccessful on the content of self-identification characteristics.

Then, on the basis of the data obtained, a factor analysis was carried out with the help of SPSS software, version 20.0 , by the method of main components with varimax rotation. As 
a result, 3 factors were obtained explaining $66.9 \%$ of the experimental group's data (198 people).

\section{Results}

The expression of identity signs in the abovementioned categories in different groups of subjects with different social success rates was recorded in the numerical indicators of frequency of occurrence (Table 1)

Table 1. Numerical indicators of frequency of occurrence.

\begin{tabular}{|l|c|c|}
\hline \multicolumn{1}{|c|}{$\begin{array}{c}\text { Identification } \\
\text { categories }\end{array}$} & $\begin{array}{c}\text { UNSUCCESSFUL. } \\
\text { (22 people - 100\%) }\end{array}$ & $\begin{array}{c}\text { SUCCESSFUL. } \\
\text { (19 people - 100\%) }\end{array}$ \\
\hline $\begin{array}{l}\text { CHARACTER, } \\
\text { ORIENTATION }\end{array}$ & $4.5 \%$ & $15.7 \%$ \\
\hline past experience & $13.6 \%$ & $21.1 \%$ \\
\hline feelings & $14.3 \%$ & $15.8 \%$ \\
\hline attitude to the world & $18.2 \%$ & $36.8 \%$ \\
\hline attitude to people & $22.7 \%$ & $47.4 \%$ \\
\hline $\begin{array}{l}\text { attitude towards } \\
\text { oneself /self-image }\end{array}$ & $0 \%$ & $26.3 \%$ \\
\hline future plans & $18.2 \%$ & $15.8 \%$ \\
\hline $\begin{array}{l}\text { ACTIVITY STYLE, } \\
\text { BEHAVIOUR }\end{array}$ & $50 \%$ & $36.8 \%$ \\
\hline habits & $4.5 \%$ & $26.3 \%$ \\
\hline $\begin{array}{l}\text { behavioral and social } \\
\text { style }\end{array}$ & & \\
\hline conversation style & & \\
\hline
\end{tabular}

Methods of mathematical statistics (N-Craskala-Wallace, single-factor ANOVA dispersion analysis on the sample $\mathrm{N}=100$ people) allowed us to determine that in conditions of prolonged social failure the greatest distinguishing features have a time vector of selfidentification features of personality.

It is this factor that significantly differs in terms of intensity among socially unsuccessful respondents from socially successful ones ( $0 \%$ and $26.3 \%$, respectively).

That is, the content of personal identity is qualitatively different in groups of subjects of different success.

In the group of socially successful subjects, identity is manifested in a greater internal constancy of the image of the Self, as well as in their clearly presented plans for the future, ensuring personal spatial and temporal continuity.

In the group of low-achieving subjects, the idea of personal constancy is based on stylistic characteristics of activity and behavior, i.e. on more volatile and external parameters.

Factoring has shown that the categories of "external" and "internal" self-identification characteristics are universal, along with the time vector (factor) of the orientation of identification processes of a person.

Thus, the analysis of the highlighted factors allowed us to clarify the structural structure of personal identity and left external/internal self-identification features, and the 3rd is a dynamic and guiding factor, the time factor. In other words, we refer to the internal selfidentification characteristics of a person's character and orientation, and to the external ones - individual style of activity and behavioral characteristics of a person. The time factor is 
"through", i.e. each of the signs mentioned above may appear in a person in the past, present or future.

The verification/non-identity verification study was conducted by counting and comparing the total identity index (factor loads). Socially unsuccessful respondents assess their identity more intensively (comparison of averages, T-student criterion), i.e. the need to feel and express their uniqueness is not satisfied, is actualized, is expressed more than that of socially successful respondents.

\subsection{Behavior}

Due to the fact that socially unsuccessful respondents are more dependent on external circumstances in their self-identification than on stable personal structures (Table 1), they have less personal autonomy and independence.

In case of social failure, an individual does not identify himself or herself through the category of "plans for the future", the personal life plan is reduced, which is manifested in clear value and meaning orientations of life with pronounced social success.

The identity of socially unsuccessful respondents is mainly oriented to the past, more rigid, and has a larger overall index of severity (load on factors).

The general index of personal identity is more pronounced among young men $(\mathrm{p}=$ $0.000 \ldots)$

Thus, young men are more oriented towards the past than adolescents and young people ( $p=0.033$ and $p=0.04$, respectively, according to the Mann Whitney criterion). Perhaps this is due to fear of the future, a period of self-determination.

Adolescents (11-15 years old) are less than young men (16-21 years old), and mature respondents (44-61 years old) are less than adults (32-43 years old) focused on external signs of identifying their own uniqueness, originality and self-identity

Adult respondents are more young and mature respondents focused on the external factor of identifications $(\mathrm{p}=0.016$ and $\mathrm{p}=0.031$, respectively) and on the style characteristics of activity ( $p=0.023$ and $p=0.003$, respectively). Perhaps this is due to the age crisis.

Therefore, when interpreting the results, we make an amendment to the fact that even with the revealed general fixation of young men on the past, in a situation of success there are orientations towards the future (vision of oneself in the future, making plans, dreams, etc.)

\section{Discussion}

Psychology theorists understand that the specific problems experienced by a person due to the changing circumstances of socialization and the transient nature of his or her identity create grounds for questions of targeted support of the person.

In this regard, researchers are faced with the problem of operationalization of structurally-containing components of personal identity, discussed in this study.

In understanding identity as a process of self-identification that unfolds in a particular situation and living space, the content of identity becomes, to varying degrees, updated formulations describing the individual from the perspective of external/internal characteristics, either in the past or in the future.

An indication of the development of identity as an ability to "master space and time" is found in I. Hoffmann and G. Garfinkel, as an opportunity to maintain the balance of identity throughout individual history to J. Habermas, as a process of interiorization and self-process in the social situation of development in L.S. Vygotsky, as the goal of organizing activities and guiding the life of a person in Kimberg A.N. in full or in part [24], etc. 
Thus, it is clear that this study, in addition to the existing theoretical foundations and empirical studies, clarifies the structural and substantive components of personal identity.

In addition, we believe that data on the unconfirmed identity of socially unsuccessful respondents deserve special attention and additional research. In the following, it is possible to test as a separate research hypothesis the assumption that the need for identity (identity, uniqueness) in socially unsuccessful respondents is more pronounced, not satisfied, and probably generates any substitutional actions in those living spaces where success is more possible.

\section{Conclusions}

Summing up this study, we note that in conditions of long-term social failure such an important parameter of personal identity as the experience of the integrity of one's own self does not develop in time, violating the ability of a person to realize and highlight clear goals, to link them to the chain of events of their future, the time plan of life of the person is violated. However, the need for personal identification in the event of social failure is more pronounced, telling the researcher that the definition of the path of life and the success or failure of self-realization is not just a choice of profession, family, way of life, it is an opportunity to find an internal balance of personality, and, most likely, subjective satisfaction with life as a whole.

\section{References}

1. D.A. Leontiev, Cultural-Historical Psychology 15(1), 25-34 (2019) https://doi.org/10.17759/chp.2019150103

2. L.A. Shaigerova, R.S. Shilko, O.V. Vakhantseva, Yu.P. Zinchenko, National Psychological Journal 3(35) (2019) https://cyberleninka.ru/article/n/perspektivyispolzovaniya-analiza-sotsialnyh-setey-dlya-izucheniya-etnokulturnoy-identichnostipodrostkov-v-internet-soobschestvah

3. A.G. Asmolov, G.A. Asmolov, Psychology in Russia 1 (2009) https://cyberleninka.ru/article/n/from-we-media-to-i-media-identity-transformations-inthe-virtual-world

4. Social psychology and society 9(3), 10-20 (2018) doi:10.17759/sps.2018090302

5. E.A. Sergienko, Psychological journal 39(2), 14-24 http://dx.doi.org/10.7868/80205959218020022

6. V.V. Znakov, Psychological research 8(42), 12 (2015) http://psystudy.ru

7. D.A. Leontiev, Cultural-historical psychology 16(2), 19-24 doi:10.17759/chp.2020160203

8. K.G. Klein, D.A. Leontiev, V.Yu. Kostenko, E.N. Osin, O.A. Taranenko, N.V. Kosheleva Psychological Science and Education 24(5), 47-57 (2019) doi: $10.17759 /$ pse.2019240505

9. T.V. Gavrilenko, Z.I. Ryabikina, Scientific journal of KubSAU 134(10) (2017) doi: 10.21515/1990-4665-134-073

10. E.A. Kaufman, B. Meddaoui, Identity pathology and borderline personality disorder: $\begin{array}{lll}\text { an empirical overview 2020) } & \end{array}$ https://doi.org/10.1016/j.copsyc.2020.08.015

11. E.A. Kaufman, S.E. Crowell, Rev. Gen. Psychol. 22, 245-263 (2018) http://dx.doi.org/10.1037/gpr0000138 
12. D. Hicks, Library \& Information Science Research 42(3), 101035 (2020) https://doi.org/10.1016/j.lisr.2020.101035

13. Y.P. Zinchenko, G.Ya. Menshikova, Y.M. Bayakovsky, A.M. Chernorizov, A.E. Voiskounsky, Psychology in Russia 1 (2010) https://cyberleninka.ru/article/n/technologies-of-virtual-reality-in-the-context-ofworldwide-and-russian-psychology-methodology-comparison-with-traditional-methods

14. I.G. Makarevskaya, Y.E. Makarevskaya, L.A. Bazaleva, Humanization of Education 5 (2019) DOI: 10.24411/1029-3388-2019-10053

15. V.I. Pischik, The mentality of generations in fluid modernity (INFRA-M, Moscow, 2019) doi:org/10.12737/monography_5ba0ee24675441.11909669

16. Z.I. Ryabikina, G.Yu. Fomenko, South-Russian Journal of Social Sciences 4 (2009) https://cyberleninka.ru/article/n/subektno-bytiynyy-podhod-preemstvennost-traditsiy

17. D. Leontyev, Russian Journal of Philosophical Sciences 10, 5-10 (2009) https://www.phisci.info/jour/article/view/1540/1472

18. N.V. Grishina, Psychological research 6, 30 (2013) http://psystudy.ru

19. N.V. Grishina, Bulletin of St. Petersburg University. Psychology and pedagogy 8(2), 126-138 (2018) https://doi.org/10.21638/11701/spbu16.2018.202

20. M.S. Guseltseva, A.G. Asmolov, Povolzhsky pedagogical search 2(32), 14-23 (2020) DOI: $10.33065 / 2307-1052-2020-2-32-14-23$

21. A. Asmolov, M. Guseltseva, European Proceedings of Social and Behavioural $\begin{array}{lllll}\text { Sciences, } & \text { Future } & \text { Academy } & \text { 64(5), } & 33-39\end{array}$ https://doi.org/10.15405/epsbs.2019.07.5

22. D.A. Leontiev, E.N. Osin, S.Sh. Dosumova, F.R. Rzayeva, V.V. Bobrov, Psychological Science and Education 23(6), 55-66 (2018) doi:10.17759/pse.2018230605

23. Yu.E. Makarevskaya, Z.I. Ryabikina, Safety psychology and psychological safety: problems of interaction between theorists and practitioners in expert psychological research, 106-109 (2018) DOI: 10.18411/sb-2018-31

24. A.N. Kimberg, Uchen. app. Kazan. un-that. Ser. Humanist. Sciences 3 (2008) 